\title{
Economic Dispatch untuk Grid Mikro Hibrida dengan Distributed Energy Storage Berbasis Metode Quadratic Programming
}

\author{
Kemas Robby Firmansyah, Rony Seto Wibowo, Adi Soeprijanto \\ Jurusan Teknik Elektro, Fakultas Teknologi Industri, Institut Teknologi Sepuluh Nopember (ITS) \\ J1. Arief Rahman Hakim, Surabaya 60111 Indonesia \\ e-mail:kemas.robby12@mhs.ee.its.ac.id, ronyseto@ee.its.ac.id, adisup@ee.its.ac.id
}

\begin{abstract}
Abstrak-Kebutuhan daya listrik saat ini meningkat pesat dengan perkembangan teknologi. Peningkatan kebutuhan daya listrik bertolak belakang dengan ketersediaan sumber energi tak terbarukan. Permasalahan ini akan berdampak pada ketahanan listrik nasional, untuk memenuhi kebutuhan daya listrik yang besar dengan wilayah yang luas diperlukan pembangkit -pembangkit tersebar dengan skala kecil. Pembangkit tersebar diupayakan bersumber pada energi terbarukan untuk meminimalkan pemakaian sumber energi tak terbarukan. Selain itu diperlukan adanya Energy Storage, Energy Storage diperlukan untuk menyimpan kelebihan energi yang dihasilkan oleh pembangkit lainnya. Dengan adanya pembangkit tersebar dan Energy Storage yang dihubungkan dengan grid utama Perusahaan Listrik Negara melaui Grid Mikro, maka penting untuk menentukan optimisasi besarnya pembangkit daya listrik untuk masing-masing pembangkit yang sesuai dengan kebutuhan daya listrik. Optimisasi ini dikenal dengan istilah Economic Dispatch. Metode yang diterapkan untuk optimisasi Economic Dispatch adalah dengan menggunakan Quadratic Programming. Simulasi dilakukan pada sistem IEEE 14 bus menggunakan software MATLAB. Hasil simulasi dan analisis menunjukkan bahwa program dapat memenuhi batasan yang ditentukan dan biaya pembangkitan tenaga listrik untuk pengoperasian Grid Mikro Hibrida adalah 25,53\$.
\end{abstract}

Kata Kunci_Energy Storage, Economic Dispatch, Grid Mikro Hibrida, Quadratic Programming.

\section{PEndahuluan}

$\mathrm{T}$ enaga listrik merupakan salah satu kebutuhan yang sangat penting dalam kehidupan manusia. Permintaaan daya listrik yang terus bertambah seiring dengan perkembangan teknologi menyebabkan daya listrik yang harus disuplai oleh pembangkit listrik menjadi besar, sehingga pemakaian sumber energi tak terbarukan menjadi pemborosan. Sumber energi yang terbarukan dan ekonomis adalah salah faktor penting dalam peningkatan perkembangan industri yang dapat meningkatkan standar hidup masyarakat. Sejak adanya revolusi industri, kebutuhan energi listrik meningkat tajam[1].

Sebagai bentuk yang baik dalam membangkitkan daya yang besar dengan cakupan wilayah yang luas, sistem pembangkitan tersebar (mikrogrid) menjadi penting untuk memenuhi permintaan beban, menaikkan keandalan, dan sebagainya [2,3]. Pembangkit tersebar tehubung grid yang umumnya menggunakan sumber energi terbarukan seperti photovoltaic dan khususnya untuk menanggung beban puncak seperti mikro turbin dan generator diesel merupakan mikrogrid sederhana. Namun seiring dengan majunya teknologi, diperlukan adanya energy storage sebagai metode efektif untuk menyimpan energi listrik dan dapat digunakan saat dibutuhkan. Dengan adanya energy storage manajemen energi yang digunakan berbeda dengan manajemen energi konvensional, karena energy storage memiliki dynamic power dan energy formulation tersendiri[4]. Untuk memenuhi permintaan beban, energi listrik dapat dihasilkan secara langsung oleh sumber energi listrik diatas bersama sama dengan grid.

Metode yang digunakan untuk menyelesaikan permasalahan diatas adalah dengan menggunakan quadratic programming[5]. Hasil dari quadratic programming dapat digunakan sebagai refrensi dalam pembangkitan daya listrik yang optimum yang sesuai dengan biaya pembangkitan listrik.

\section{ECONOMIC AND EMISSION DISPATCH}

\section{A. Model Operasi Sistem Grid Mikro Hibrida}

Model operasi sistem grid mikro hibrida yang dipakai adalah grid-connected. Dengan tipe operasi ini, Perusahaan Listrik Negara (PLN) sebagai grid utama diintegrasikan kedalam sistem mikrogrid sehingga pembangkit tersebar yang terpasang tidak menanggung semua kebutuhan beban dalam sistem. Beberapa sumber energi listrik yang dimodelkan dalam sistem mikrogrid hybrid adalah energy storage, generator diesel, mikro turbin, sel surya, dan PLN.

\section{B. Energy Storage}

Energy storage mempunyai batas teknis keadaan energi maksimum dan minimun, dan juga daya saat charging dan discharging. Batasan ini dapat dianggap fungsi waktu untuk memodelkan monitoring kesehatan dan keandalan dari energy storage[6]. Batasan teknis dapat diekspresikan dibawah ini:

$$
\begin{aligned}
& -P_{E S, c h, \max } \leq P_{E S}(t) \leq P_{E S, d s, \max } \\
& E_{E S, \min } \leq E_{E S}(t) \leq E_{E S, \max } \\
& E_{E S}(t)=E_{E S}(t-1)-P_{E S}(t) * K \\
& t=1,2, \ldots, T
\end{aligned}
$$

Biaya operasi dari energy storage adalah[7]:

$$
C F\left(P_{E S}\right)=b P
$$

Dimana:

$C F\left(P_{E S}\right)$ total biaya operasi energy storage dalam USD/h.

$b \quad$ koefisien energy storage, dengan masing masing nilai $\mathrm{b}=0,119$.

$P_{E S} \quad$ keluaran daya dari energy storage $M W$. 


\section{Generator Diesel}

Generator Diesel sudah dikembangkan lebih dari 100 tahun yang lalu. Teknologi ini merupakan yang pertama digunakan dalam sistem pembangkit tersebar. Generator Diesel ini banyak digunakan di berbagai sektor ekonomi dengan skala yang berbeda mulai dari $1 \mathrm{~kW}$ hingga berpuluh-puluh $M W$. Pembangkit ini banyak digunakan karena memiliki efisiensi dan keandalan yang tinggi.

Generator Diesel adalah jenis yang paling umum digunakan dalam teknologi Micro Grid saat ini. Biaya operasi dari sistem dapat dinyatakan sebagai fungsi daya keluaran dan dapat dimodelkan dengan polinomial kuadrat. Biaya operasi untuk generator diesel adalah sebagai berikut :

$$
C F\left(P_{D G}\right)=a+b P_{D G}+c P_{D G}^{2}
$$

Dimana:

$C F\left(P_{D G}\right)$ total biaya operasi generator diesel dalam $U S D / h$.

$a, b$, dan $c$ koefisien generator, dengan masing-masing nilai $\mathrm{a}=14,88, \mathrm{~b}=0,3$, dan $\mathrm{c}=0,0004351$.

$P_{D G} \quad$ keluaran daya dari generator diesel dalam $M W$.

\section{Turbin Mikro}

Turbin mikro merupakan generator turbin gas kecepatan tinggi bertenaga mulai 25-500 $\mathrm{kW}$. Turbin mikro mempunyai sistem yang mengubah energi mekanik menjadi energy listrik. Frekuensinya berada pada rentang 1.4-4 $\mathrm{kHz}$. Frekuensi tinggi ini diubah ke frekuensi yang diinginkan $50 / 60 \mathrm{~Hz}$ menggunakan konverter.

Biaya operasi yang digunakan dalam tugas akhir ini adalah sebagai berikut:

$$
C F\left(P_{M T}\right)=a+b P_{M T}+c P_{M T}^{2}
$$

Dimana:

$\mathrm{CF}\left(P_{M T}\right)$ total biaya operasi turbin mikro dalam $U S D / \mathrm{h}$.

a, b, dan c koefisien turbin mikro, dengan masingmasing nilai $a=9, b=0,36$, dan $c=0,000315$. $P_{M T} \quad$ keluaran daya dari turbin mikro dalam $M W$.

\section{E. Sel Surya}

Pembangkit sel surya merupakan sistem yang mengubah cahaya matahari secara langsung menjadi energi listrik. Karakteristik dari sel surya saat beroperasi berbeda dengan kondisi standar $\left(1000 \mathrm{~W} / \mathrm{m}^{2}\right.$, suhu sel $25^{\circ} \mathrm{C}$ ) maka pengaruh radiasi dan suhu pada karakeristik sel surya dimodelkan. Pengaruh intensitas matahari dimodelkan dengan mempertimbangkan output daya dari modul sel surya yang akan sebanding dengan radiasinya. Modul sel surya diuji dalam Standard Test Condition (STC). Daya keluaran dari modul sel surya dapat dihitung dengan persamaan :

$$
P p v=M\left(P s t c \frac{\text { Ging }}{\text { Gstc }}+(1+k(T c-T r))\right.
$$

Dimana :

$P_{P V} \quad$ daya keluaran dari modul saat radiasi.

$G_{I N G}$ daya maksimum modul saat $\operatorname{STC}(W)$.

$G_{I N G}$ radiasi aktual dalam

$G_{S T C}$ radiasi saat $S T C\left(1000 \mathrm{~W} / \mathrm{m}^{2}\right)$.

$M \quad$ jumlah modul sel surya.

$K \quad$ koefisien suhu untuk daya modul $\left(\% /{ }^{\circ} \mathrm{C}\right)$.

$T_{C} \quad$ suhu sel referensi suhu $\left(25^{\circ} \mathrm{C}\right)$.

Biaya operasi untuk sel surya adalah sebagai berikut:

$$
C F\left(P_{P V}\right)=b P_{P V}
$$

Dimana:

$C F\left(P_{P V}\right)$ total biaya operasi sel surya dalam $U S D / h$.

$b \quad$ koefisien sel surya, dengan masing-masing nilai $b=0,55$.

$P_{P V} \quad$ keluaran daya dari sel surya dalam $M W$.

\section{F. Perusahaan Listrik Negara}

Dalam sistem grid-connected ini, Perusahaan Listrik Negara (PLN) diintegrasikan ke mikrogrid. PLN diasumsikan mempunyai daya yang terbatas, karena PLN memiliki cost function tersendiri. Berikut perhitungan cost function dari PLN:

$$
\begin{array}{ll}
\text { Harga listrik per } k w h[8] & : \text { Rp. } 1.342,98 \\
\text { Kurs IDR ke USD }(\mathrm{K}) & : \text { Rp. } 13.333,33 \\
\text { Cost Function }\left(C F\left(P_{P L N}\right)\right) & : \frac{l}{K \times 1000}
\end{array}
$$

Dimana:

$C F\left(P_{P L N}\right)$ total biaya operasi PLN dalam $U S D / h$.

$P_{P L N} \quad$ keluaran daya dari PLN dalam $M W$.

\section{ECONOMIC DISPATCH}

Economic Dispatch merupakan pembagian pembebanan pada pembangkit untuk beroperasi secara ekonomis pada kondisi beban sistem tertentu. Fungsi total biaya dari masing-masing pembangkit dimodelkan dengan persamaan:

$$
\begin{aligned}
C F(P)= & C F\left(P_{E S}\right)+C F\left(P_{D G}\right)+C F\left(P_{M T}\right)+ \\
& C F\left(P_{P V}\right)+C F\left(P_{P L N}\right)
\end{aligned}
$$

Economic Dispatch memiliki constraint untuk dapat beroperasi. Constraint ini terbagi menjadi dua yaitu equality constraint dan inequality constraint.

1. Equality constraint

$$
P_{\text {load }}=\sum_{i=1}^{N} P_{i}
$$

2. Inequality constraint

$$
\begin{aligned}
& P_{i}^{\text {min }} \leq P_{i} \leq P_{i}^{\text {max }} \\
& -P_{E S, \text { ch, } \max } \leq P_{E S}(t) \leq P_{E S, d s, \max } \\
& E_{E S, \min } \leq E_{E S}(t) \leq E_{E S, \max } \\
& E_{E S}(t)=E_{E S}(t-1)-P_{E S}(t) * a \\
& t=1,2, \ldots, T \\
& \text { Dimana: }
\end{aligned}
$$$$
P_{\text {load }}
$$$$
\sum_{i=1}^{N} P_{i}
$$$$
\text { total beban sistem dalam } M W \text {. }
$$$$
\text { total daya terbangkitkan oleh masing- }
$$$$
\text { masing pembangkit listrik. }
$$$$
P_{i}^{\min } \quad \text { batas bawah daya terbangkitkan }
$$$$
\text { pembangkit. }
$$$$
P_{i} \quad \text { daya terbangkitkan pembangkit. }
$$$$
P_{i}^{\max } \quad \text { batas atas daya terbangkitkan }
$$$$
\text { pembangkit. }
$$$$
-P_{E S, c h, \max } \text { batas daya terbangkitkan energy }
$$$$
\text { storage saat keadaan charging. }
$$$$
P_{E S}(t) \quad \text { daya terbangkitkan energy storage. }
$$$$
P_{E S, d s, \text { max }}(t) \text { batas daya terbangkitkan energy }
$$$$
\text { storage saat keadaan discharging. }
$$$$
E_{E S, \min }(t) \quad \text { batas bawah keadaan energi energy }
$$$$
\text { storage. }
$$$$
E_{E S}(t) \quad \text { keadaan energi energy storage. }
$$$$
E_{E S, \max }(t) \text { batas atas keadaan energi energy }
$$$$
\text { storage. }
$$

K konstanta konversi watt ke joule.

$t \quad$ waktu optimasi. 


\section{ECONOMIC DisPatCH DENGAN METODE QUADRATIC PROGRAMMING}

\section{A. Quadratic Programming}

Salah satu metode perhitungan optimasi yaitu quadratic programming. Quadratic programming menyelesaikan permasalahan optimasi dengan fungsi objektif berupa persamaan kuadrat dan batasan batasan linear. Batasan linear dapat berupa persamaan atau equality constraints atau berupa inequality constraints [9]. Persamaan umum quadratic programming dapat dituliskan sebagai berikut:

1. Fungsi objektif :

$$
F(x)=f+g^{T} x+\frac{1}{2} x^{T} H x
$$

2. Inequality constraint:

$$
\begin{aligned}
& l b \leq A x \leq u b \\
& x_{\text {min }} \leq x \leq x_{\text {max }} \\
& \text { 3. Equality constraints: } \\
& l b=u b=b_{e q} \\
& A x=b_{e q}
\end{aligned}
$$

Hasil perhitungan quadratic programming yaitu menentukan nilai $\mathrm{x}$ yang menghasilkan fungsi objektif dengan nilai minimum.

\section{B. Penyelesaian Economic Dispatch dengan Quadratic Programming}

1) Penyusunan Koefisien Kuadrat Fungsi Biaya Pembangkitan

Variabel $\mathrm{H}$ adalah koefisien kuadrat dari fungsi objektif pada quadratic programming. Pada Economic Dispatch Mikrogrid Hybrid dengan Distributed Energy Storage, $\mathrm{H}$ merupakan matriks simetris yang berisi koefisien kuadrat fungsi biaya pembangkitan untuk masing-masing pembangkituntuk kurun waktu t. Matriks $\mathrm{H}$ memiliki ukuran [[nb+ng:nb+ng]*t], dimana nb adalah jumlah bus, ng adalah jumlah pembangkit, dan $\mathrm{t}$ adalah waktu operasi sistem. Untuk menggambarkan pembentukan matriks $\mathrm{H}$ serta variabel lainnya dalam penyelesaian Economic Dispatch dengan Quadratic Programming ini, digunakan model sistem kelistrikan sederhana dengan 3 bus, 2 saluran transmisi, dan 2 pembangkit yang terdirai atas sel surya dan energy storage. Sistem kelistrikan diasumsikan beroperasi selama 2 jam.

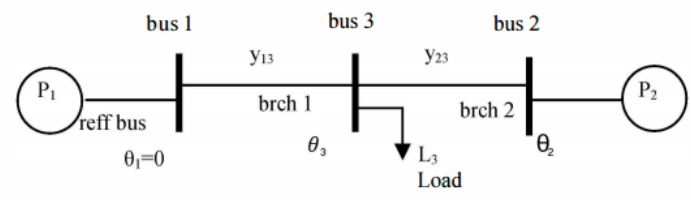

Gambar 1. Contoh sistem kelistrikan sederhana

Dengan sistem kelistrikan diatas, matriks H yang dapat dibentuk adalah sebagai berikut:

$$
H=\left[\begin{array}{cccccccccc}
0 & 0 & 0 & 0 & 0 & 0 & 0 & 0 & 0 & 0 \\
0 & 0 & 0 & 0 & 0 & 0 & 0 & 0 & 0 & 0 \\
0 & 0 & 0 & 0 & 0 & 0 & 0 & 0 & 0 & 0 \\
0 & 0 & 0 & a_{11} & 0 & 0 & 0 & 0 & 0 & 0 \\
0 & 0 & 0 & 0 & a_{21} & 0 & 0 & 0 & 0 & 0 \\
0 & 0 & 0 & 0 & 0 & 0 & 0 & 0 & 0 & 0 \\
0 & 0 & 0 & 0 & 0 & 0 & 0 & 0 & 0 & 0 \\
0 & 0 & 0 & 0 & 0 & 0 & 0 & 0 & 0 & 0 \\
0 & 0 & 0 & 0 & 0 & 0 & 0 & 0 & a_{12} & 0 \\
0 & 0 & 0 & 0 & 0 & 0 & 0 & 0 & 0 & a_{22}
\end{array}\right]
$$

Keterangan:

$a_{12}$, koefisien kuadrat fungsi biaya pembangkitan pembangkit 1 jam ke 2 .

\section{2) Variabel Optimasi $(x)$}

Variabel optimasi (x) merupakan nilai yang dihasilkan dari proses optimasi. Nilai ini berisi sudut tegangan tiap bus dan daya aktif yang dibangkitkan oleh pembangkit untuk tiap waktu tertentu. Matriks ini disusun sejumlah waktu operasi sistem (t), sehingga matriks $\mathrm{x}$ memiliki ukuran $[[(\mathrm{nb}+\mathrm{ng}): 1] * \mathrm{t}]$. Bentuk matriks x yang dihasilkan adalah sebagai berikut:

$$
x=\left[\begin{array}{l}
\theta_{11} \\
\theta_{21} \\
\theta_{31} \\
P_{11} \\
P_{21} \\
\theta_{12} \\
\theta_{22} \\
\theta_{32} \\
P_{12} \\
P_{22}
\end{array}\right]
$$

Keterangan:

$\theta_{12}$, sudut tegangan pada bus 1 jam ke- 2 .

$P_{12}$, daya aktif yang dibankitkan oleh pembangkit 1 pada jam ke-2.

\section{3) Penyusunan Batasan (Constraint)}

Batasan permasalahan economic dispatch mikrogrid hybrid dengan distributed energy storage direpresentasikan dengan matriks $A$. Matriks $A$ tersusun atas $\left[A_{\text {eq }}\right]$ untuk equality constraint dan $\left[\mathrm{A}_{\text {ineq }}\right]$ untuk inequality constraint. $\left[A_{e q}\right]$ tersusun atas matriks yang berisi batasan power balance $[P G]$ dengan ukuran $[[\mathrm{nb}:(\mathrm{nb}+\mathrm{ng})] * \mathrm{t}], \quad$ constraint energy storage $[E S]$ berukuran $[1:(n b+n g)]$, dan constraint sel surya $[P V]$ berukuran $[1:(\mathrm{nb}+\mathrm{ng})]$ untuk mengubah nilai $p$-max dari $p v$ untuk tiap jamnya. Matriks $[E S]$ dan $[P V]$ masing masing berjumlah $t$ untuk sistem kelistrikan yang dioptimasi selama waktu $t$.

$$
\begin{gathered}
P G=\left[\begin{array}{ccccccc}
y_{13} & 0 & -y_{13} & -1 & 0 \\
0 & y_{23} & -y_{23} & 0 & -1 \\
-y_{31} & -y_{32} & y_{33} & 0 & 0
\end{array}\right] \\
E S=\left[\begin{array}{llllllllll}
0 & 0 & 0 & 1 & 0 & 0 & 0 & 0 & 0 & 0 \\
0 & 0 & 0 & 1 & 0 & 0 & 0 & 0 & 1 & 0
\end{array}\right] \\
P V=\left[\begin{array}{llllllllll}
0 & 0 & 0 & 0 & 1 & 0 & 0 & 0 & 0 & 0 \\
0 & 0 & 0 & 0 & 0 & 0 & 0 & 0 & 0 & 1
\end{array}\right]
\end{gathered}
$$

Pada matriks $[E S]$ dan $[P V]$, baris pertama menyatakan jam ke-1 dan baris kedua menyatakan jam ke-2. Matriks $\left[A_{\text {ineq }}\right]$ berisi batasan saluran transmisi [PIN]. Matriks ini berukuran $[(2 * n b r):(n b+n g)]$, kemudian matriks ini disusun sesuai dengan jumlah waktu $t$ yang ditentukan.

$$
P I N=\left[\begin{array}{ccccc}
y_{13} & 0 & -y_{13} & 0 & 0 \\
0 & y_{23} & -y_{23} & 0 & 0 \\
-y_{13} & 0 & y_{13} & 0 & 0 \\
0 & -y_{23} & y_{23} & 0 & 0
\end{array}\right]
$$

Kedua matriks $\left[A_{e q}\right]$ dan $\left[A_{\text {ineq }}\right]$ kemudian digabungkan menjadi matriks $[A]$. Sementara matriks $[E S]$ dan $[P V]$ diletakkan pada bagian paling bawah.

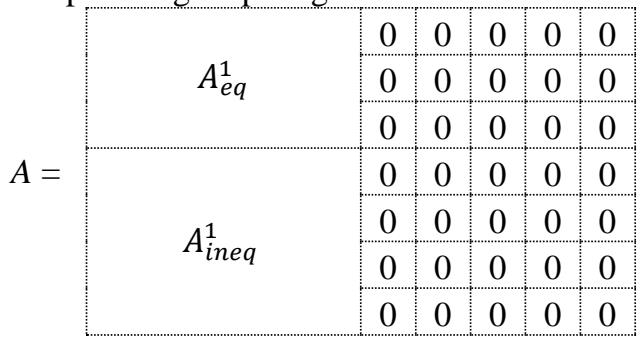




\begin{tabular}{|c|c|c|c|c|c|}
\hline 0 & 0 & 0 & 0 & 0 & \multirow{3}{*}{$A_{e q}^{2}$} \\
\hline 0 & 0 & 0 & 0 & 0 & \\
\hline 0 & 0 & 0 & 0 & 0 & \\
\hline 0 & 0 & 0 & 0 & 0 & \multirow{4}{*}{$A_{\text {ineq branch }}^{2}$} \\
\hline 0 & 0 & 0 & 0 & 0 & \\
\hline 0 & 0 & 0 & 0 & 0 & \\
\hline 0 & 0 & 0 & 0 & 0 & \\
\hline \multicolumn{6}{|c|}{$E S$} \\
\hline \multicolumn{6}{|c|}{$P V$} \\
\hline
\end{tabular}

Setelah terbentuk matriks $[A]$, maka didapatkan persamaan sebagai berikut:

$$
[A] *[x]=[Z]
$$

Nilai matriks [Z] harus memenuhi equality constraint dan inequality constrain yang telah ditentukan di economic dispatch[10].

\section{HASIL DAN ANALISIS}

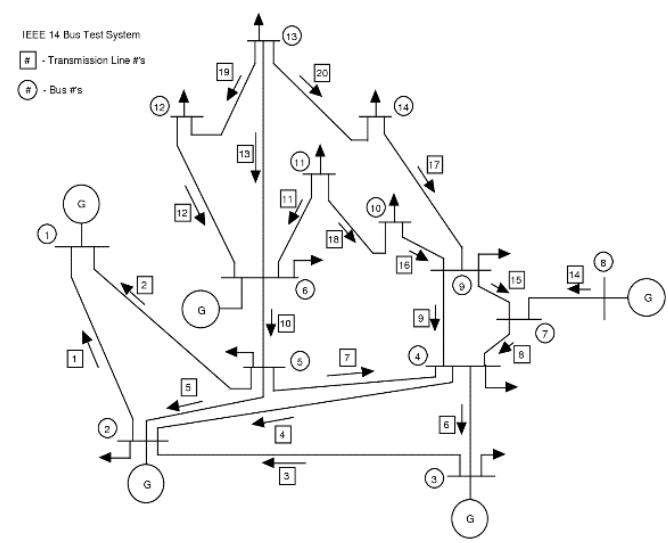

Gambar 2. Sistem grid mikro hibrida

TABEL 1. SPESIFIKASI TIAP UNIT PEMBANGKIT Unit 1 Unit 2 Unit 3 Unit 4 Unit 5

\begin{tabular}{r|ccccc} 
Jumlah Modul & 1 & 1 & 1 & 37 & 1 \\
$P_{\max }(M W)$ & 0,01 & 0,25 & 0,2 & 0,1 & 0,1 \\
$P_{\min }(M W)$ & $-0,01$ & 0,05 & 0,05 & 0 & 0 \\
$\mathrm{a}(\$ / H)$ & - & 14,88 & 9 & - & - \\
$\mathrm{b}(\$ / M W H)$ & 0,119 & 0,3 & 0,3 & 0,545 & 0,00013 \\
$c\left(\$ / M W^{2} H\right)$ & - & 0,000435 & 0,000315 & - & - \\
$\mathrm{Kapasitas}_{(M W H)}$ & 0,2 & - & - & - & - \\
$S O C_{\max }(M W H)$ & 0,16 & - & - & - & - \\
$S O C_{\min }(M W H)$ & 0,04 & - & - & - & -
\end{tabular}

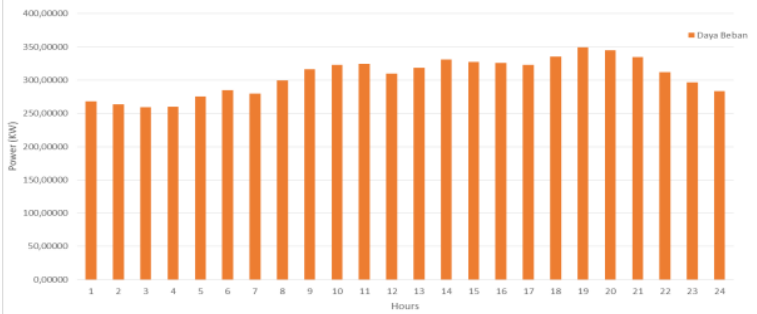

Gambar 3. Profil beban grid mikro hibrida

TABEL 2. DAYA TERBANGKITKAN TIAP UNIT PEMBANGKIT

\begin{tabular}{llllll}
\hline \hline T & Unit 1 & Unit 2 & Unit 3 & Unit 4 & Unit 5 \\
\hline 1 & 5,96 & 80,53 & 81,82 & 0,00 & 100,00
\end{tabular}

\begin{tabular}{llllll}
\hline 2 & 5,68 & 78,68 & 79,67 & 0,00 & 100,00 \\
3 & 5,39 & 75,77 & 77,84 & 0,00 & 100,00 \\
4 & 5,39 & 76,07 & 78,27 & 0,00 & 100,00 \\
5 & 6,23 & 83,32 & 85,85 & 0,00 & 100,00 \\
6 & 6,75 & 88,58 & 89,91 & 0,00 & 100,00 \\
7 & $-10,00$ & 72,12 & 80,00 & 37,91 & 99,99 \\
8 & $-10,00$ & 71,92 & 79,38 & 58,63 & 99,99 \\
9 & $-10,00$ & 72,02 & 79,95 & 74,17 & 99,99 \\
10 & $-10,00$ & 72,99 & 83,50 & 76,77 & 99,99 \\
11 & $-10,00$ & 70,00 & 77,59 & 87,13 & 99,99 \\
12 & $-10,00$ & 60,01 & 60,11 & 99,99 & 99,99 \\
13 & $-10,00$ & 71,78 & 79,98 & 76,77 & 99,99 \\
14 & $-10,00$ & 87,31 & 89,98 & 63,81 & 99,99 \\
15 & $-10,00$ & 86,96 & 89,56 & 61,22 & 99,99 \\
16 & $-2,56$ & 89,96 & 92,95 & 45,68 & 100,00 \\
17 & 8,03 & 100,79 & 114,24 & 0,00 & 100,00 \\
18 & 8,91 & 101,79 & 124,69 & 0,00 & 100,00 \\
19 & 9,72 & 109,78 & 129,87 & 0,00 & 100,00 \\
20 & 9,42 & 107,71 & 127,67 & 0,00 & 100,00 \\
21 & 8,91 & 101,79 & 124,13 & 0,00 & 100,00 \\
22 & 8,03 & 100,79 & 103,29 & 0,00 & 100,00 \\
23 & 7,36 & 94,26 & 94,94 & 0,00 & 100,00 \\
24 & 6,75 & 87,78 & 89,07 & 0,00 & 100,00 \\
\hline \hline & & & & & \\
\hline
\end{tabular}

Keterangan:

Unit 1 Energy Storage $(k W)$.

Unit 2 Diesel Generator $(k W)$.

Unit 3 Microturbinek $(k W)$.

Unit 4 Sel Surya $(k W)$.

Unit 5 PLN $(k W)$.

Hasil simulasi menunjukkan bahwa jumlah daya aktif yang terbangkitkan oleh masing-masing unit pembangkit untuk tiap jamnya adalah 7349,02 $\mathrm{kW}$ dan sesuai dengan jumlah daya beban yang dibutuhkan yaitu 7349,02 $\mathrm{kW}$ (power balance). Selain itu, daya yang dibangkitkan oleh masing-masing unit pembangkit memenuhi batas daya aktif yang mampu dibangkitkan $\left(P_{G, i, \min } \leq P_{G, i} \leq\right.$ $\left.P_{G, i, \max }\right)$

\begin{tabular}{|c|c|c|c|}
\hline \multicolumn{4}{|c|}{$\omega_{\infty}^{\infty}+\infty$} \\
\hline${ }_{3000}$ & & 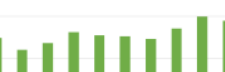 & \\
\hline \multirow{2}{*}{\multicolumn{4}{|c|}{$\begin{array}{l}\text { Gambar 4. Daya terbangkitkan pada mikrogrid hybrid } \\
\text { TABLE 3. PROFIL ENERGI ENERGY STORAGE }\end{array}$}} \\
\hline & & & \\
\hline $\mathbf{T}$ & $\begin{array}{l}\text { Fluktuasi Energy } \\
\text { Storage }(\mathrm{kW})\end{array}$ & $\begin{array}{l}\text { Fluktuasi Energy } \\
\text { Storage }(k J)\end{array}$ & $\begin{array}{l}\text { Energy } \\
\text { Storage }(k D)\end{array}$ \\
\hline 0 & 0,00 & 0,00 & 360000,00 \\
\hline 1 & 5,96 & 21445,13 & 338554,87 \\
\hline 2 & 5,68 & 20433,35 & 318121,52 \\
\hline 3 & 5,39 & 19402,77 & 298718,75 \\
\hline 4 & 5,39 & 19402,77 & 279315,98 \\
\hline 5 & 6,23 & 22431,32 & 256884,66 \\
\hline 6 & 6,75 & 24313,90 & 232570,76 \\
\hline 7 & $-10,00$ & $-35986,04$ & 268556,80 \\
\hline 8 & $-10,00$ & $-35986,04$ & 304542,85 \\
\hline 9 & $-10,00$ & $-35985,81$ & 340528,66 \\
\hline 10 & $-10,00$ & $-35986,74$ & 376515,40 \\
\hline
\end{tabular}




\begin{tabular}{llll}
\hline 11 & $-10,00$ & $-35987,50$ & 412502,90 \\
12 & $-10,00$ & $-35990,01$ & 448492,91 \\
13 & $-10,00$ & $-35989,28$ & 484482,19 \\
14 & $-10,00$ & $-35987,12$ & 520469,31 \\
15 & $-10,00$ & $-36000,04$ & 556469,35 \\
16 & $-2,56$ & $-9219,49$ & 565688,85 \\
17 & 8,03 & 28903,52 & 536785,33 \\
18 & 8,91 & 32075,76 & 504709,58 \\
19 & 9,72 & 34991,71 & 469717,87 \\
20 & 9,42 & 33916,66 & 435801,21 \\
21 & 8,91 & 32075,76 & 403725,45 \\
22 & 8,03 & 28903,52 & 374821,94 \\
23 & 7,36 & 26494,12 & 348327,82 \\
24 & 6,75 & 24313,90 & 324013,91 \\
& Min Value $(k J)$ & & 232570,76 \\
& Max Value $(k J)$ & & 565688,85 \\
\hline \hline
\end{tabular}

Keterangan:

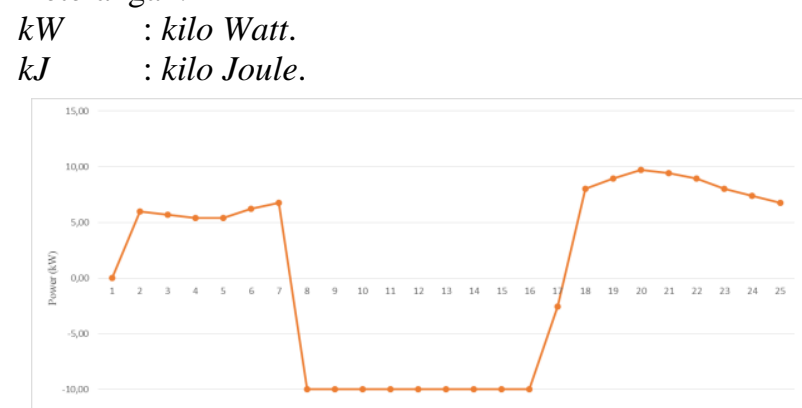

Gambar 5. Pertukaran daya energy storage

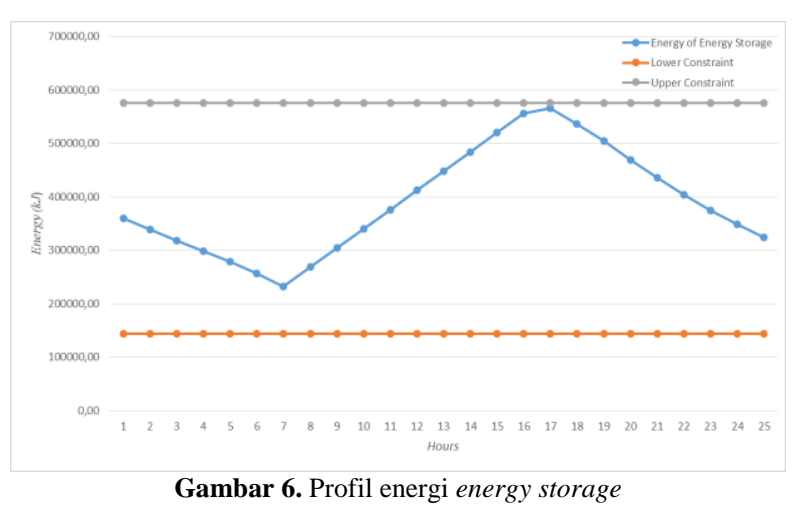

Hasil simulasi menunjukkan bahwa selama pembangkitan, fluktuasi energi energy storage tidak melanggar constraint energy storage, hal ini dibuktikan dengan nilai minimum energi energy storage adalah 232570,76 kJoule yang terjadi pada pikul ke-6 dan nilai maksimum energi energy storage adalah 565688,85 kJoule yang terjadi pada pukul ke-16.

TABEL 4. TOTAL HARGA PEMBANGKITAN GRID MIKRO HIBRIDA

\begin{tabular}{ll}
\hline \hline Generation Unit & Biaya $(\$)$ \\
\hline Energy Storage & 0,00119 \\
Generator Diesel & 15,49464 \\
Turbin Mikro & 9,66583 \\
Sel Surya & 0,37174 \\
PLN & 0,00031 \\
Total $(\$)$ & 25,53370 \\
\hline \hline
\end{tabular}

\section{KESIMPULAN}

Dari hasil dan analisis yang telah dilakukan, dapat disimpulkan beberapa hal sebagai berikut:
1. Quadratic programming dapat digunakan untuk optimasi economic dispatch grid mikro hibrida dengan distributed energy storage.

2. Pada optimasi economic dispatch mikrogrid hybrid dengan distributed energy storage, pembangkit yang dioperasikan untuk menghasilkan daya yang dibangkitkan sebesar 7349,02 $\mathrm{kW}$ dan sesuai dengan jumlah permintaan daya beban yang dibutuhkan yaitu $7349,02 \mathrm{~kW}$.

3. Selama operasi pembangkitan, fluktuasi energi energy storage tidak melanggar constraint energy storage, hal ini dibuktikan dengan nilai minimum energi energy storage adalah 232570,76 kJoule dan nilai maksimum energi energy storage adalah 565688,85 kJoule.

4. Biaya pembangkitan tenaga listrik masing-masing unit pembangkit untuk mengoperasikan grid mikro hibrida berjumlah 25,534 \$.

5. Quadratic programming adalah metode untuk menyelesaikan persamaan matematis yang bersifat linear dan non-linear, sehingga nilai yang dihasilkan bersifat mutlak.

\section{DAFTAR PUSTAKA}

[1] Imam Robandi, "Modern Power System Control", Penerbit ANDI, Yogyakarta, 2009.

[2] WANG Jiang-hai, TAI Neng-ling, SONG Kai, "Penetration Level Permission of for DG in Distributed Network Considering Relay Protection," Proceedings of the CSEE, 30 (2010), No. 22, 37-43.

[3] YU Kun, CAO Yijia, CHEN Xingying, "Dynamic Probability Power Flow of District Grid Containing Distributed Generation," Proceedings of the CSEE, 31 (2011), No. 1, 20-25.

[4] Mishel Mahmoodi, Pourya Shamsi, Babak Fahimi, "Economic dispatch of a hybrid microgrid with distributed energy storage" IEE Trans. On Smart Grid, vol 6, no. 6, November 2015.

[5] M. Vinod and C. Saurabh,"Fuel Cost Optimization of an Islanded Microgrid Considering Environmental Impact", Journal of Clean Energy Technologies, Vol. 4, No. 2, March 2016.

[6] Y. Xiao, C. Lin, and B. Fahimi,"Online State of Charge Estimationin Electrochemical Batteries: Application of Pattern Recognition Techniques,” in Proc.2013 28th Annu. IEEE Appl. Power Electron. Conf. Expo. (APEC), Long Beach, CA, USA, pp.2474-2478.

[7] R. Sundari, S. Bayne, M. Giesselmann, "Economic Dispatch Optimization of Microgrid in Islanded Mode", in IESC, Texas Tech University, 2014.

[8] PLN, "Penetapan Penyesuaian Tarif Tenaga Listrik Bulan April 2016", PLN, Jakarta, 2016.

[9] Jensen, Paul A., Bard, Jonathan F., “Operations Research Models and Methods", Wiley, 2002.

[10] L. Nani, Rony Seto, Sjamsjul Anam,’Dynamic DC Optimal Power Flow Mempertimbangkan Kontrak Energi Listrik pada Pembangkit Listrik Tenaga Panas Bumi Menggunakan Skema Take or Pay", Jurusan Teknik Elektro ITS, Surabaya, 2015.

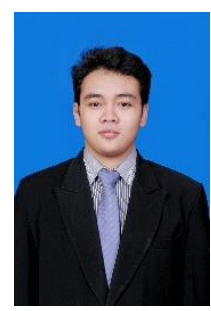

\section{BIOGRAFI PENULIS}

Penulis bernama Kemas Robby Firmansyah. Penulis menjalani pendidikan dasar di SD Negeri $3 \mathrm{Cepu}$, kemudian lulus di SD Negeri 2 Bareng Lor, Klaten. Selanjutnya pendidikan menengah pertama dilanjutkan dan lulus di SMP Negeri 2 Cepu. Penulis 
melanjutkan pendidikan menengah atas dan Pada tahun 2012 dan 2013, Penulis lolos menjadi menyelesaikannya di SMA Negeri 1 Klaten. finalis pada Pekan Ilmiah Mahasiswa Nasional 26 yang

Pada tahun 2012, penulis memulai pendidikan di Jurusan Teknik Elektro ITS melalui jalur SNMPTN. Selama menjalani masa perkuliahan, penulis aktif di beberapa organisasi antara lain UKM Robotika ITS dan Divisi Workshop Elektro ITS. diadakan di Universitas Mataram dan penulis meraih juara 3 kategori presentasi dalam bidang Program Kreatifitas Mahasiswa Pengabdian Masyarakat. Penulis dapat dihubungi melalui kemas.robby246@gmail.com 